\title{
FAKTOR YANG MEMPENGARUHI KEBERADAAN KAWASAN PERMUKIMAN KUMUH DI SURAKARTA
}

\author{
Maresty Krisandriyana ${ }^{1}$, Winny Astuti ${ }^{1}$, Erma Fitriarini ${ }^{1}$ \\ 1Program Studi Perencanaan Wilayah dan Kota Fakultas Teknik Universitas Sebelas Maret Surakarta
}

\begin{abstract}
Abstrak
Kawasan permukiman kumuh merupakan kawasan yang terabaikan dari pembangunan kota dengan kondisi lingkungan permukiman yang mengalami penurunan kualitas fisik, sosial ekonomi dan sosial budaya dan dihuni oleh orang-orang miskin, penduduk yang padat, serta dengan sarana prasarana yang minim. Di Surakarta terdapat tiga tipologi kawasan permukiman kumuh, yaitu kawasan permukiman kumuh bantaran sungai, kawasan permukiman kumuh padat perkotaan dan kawasan permukiman kumuh sepanjang rel kereta api. Banyak faktor yang dapat mempengaruhi keberadaan kawasan permukiman kumuh. Faktor-faktor tesebut antara lain urbanisasi, sarana prasarana, ekonomi, lahan perkotaan, tata ruang, daya tarik perkotaan, sosial budaya, status kepemilikan bangunan dan lama tinggal penghuni. Penelitian ini dilakukan untuk mengetahui faktor prioritas yang mempengaruhi keberadaan kawasan permukiman kumuh di Surakarta dengan menggunakan analisis prioritas (Analytic Hierarchi Process). Berdasarkan analisis AHP, faktor prioritas yang mempengaruhi keberadaan kawasan permukiman kumuh di Surakarta berbeda tiap tipologinya. Faktor prioritas kawasan permukiman kumuh bantaran sungai adalah faktor lahan perkotaan, faktor tata ruang dan faktor status kepemilikan bangunan. Faktor prioritas yang mempengaruhi keberadaan kawasan permukiman kumuh padat perkotaan yaitu faktor lahan perkotaan, faktor tata ruang dan faktor ekonomi. Sedangkan faktor prioritas yang mempengaruhi keberadaan kawasan permukiman kumuh sepanjang rel kereta api adalah faktor status kepemilikan bangunan, faktor ekonomi dan faktor tata ruang
\end{abstract}

Kata kunci: Kawasan Permukiman Kumuh, Faktor yang Mempengaruhi Keberadaan Kawasan Permukiman Kumuh, AHP

\begin{abstract}
Slum areas are neglected areas of urban development with the condition of settlement neighborhoods that experience a decline in physical, socio-economic and socio-cultural qualities and are inhabited by poor people, densely populated, and with minimal infrastructure. In Surakarta there are three typologies of slum areas, dwelling slums, densely populated urban slum dwellings and slum dwellings along the railroad tracks. Many factors can affect the existence of slum areas. These factors include urbanization, infrastructure, economy, urban land, spatial, urban attraction, socio-culture, building ownership status and duration of residence. This research was conducted to find out the priority factor that influence the existence of slum area in Surakarta by using Analytic Hierarchi Process. Based on the AHP analysis, the priority factors affecting the existence of slum areas in Surakarta differ by their typology. Priority factor of slum settlement area is urban land factor, spatial factor and ownership status factor. Priority factors affecting the existence of urban slum dwelling areas are urban land, spatial and economic factors. While the priority factors that affect the existence of slum areas along the railway is the status factor of building ownership, economic factors and spatial factors
\end{abstract}

Keywords: Slum Areas, Factors Affecting the Existence of Slum Areas, AHP

\section{PENDAHULUAN}

Dalam suatu kota tentu mengalami permasalahan akibat semakin pesatnya pertumbuhan penduduk yang tentunya berdampak pada aspek kehidupan, terutama mengenai permukiman. Apabila tidak diimbangi dengan kemampuan untuk membangun perumahan yang layak dan semakin terbatasnya lahan perkotaan untuk membangun permukiman yang mencukupi dan memenuhi syarat tentu akan menimbulkan permukiman yang kurang layak atau kumuh. Terdapat faktor yang mempengaruhi keberadaan kawasan permukiman kumuh, yaitu faktor urbanisasi, faktor sarana prasarana, faktor sosial ekonomi, faktor tata ruang dan faktor lahan perkotaan (Rindrojono, 2013). Sedangkan menurut Surtiani (2006) faktor yang dapat mempengaruhi keberadaan kawasan permukiman kumuh adalah faktor lama 
tinggal penghuni, sosial ekonomi, dan status kepemilikan lahan. Berdasarkan Kementerian Pekerjaan Umum dan Perumahan Rakyat, 2014 adapun faktor yang mempengaruhi adanya kawasan permukiman kumuh adalah faktor sosial budaya, urbanisasi, lahan perkotaan, daya tarik perkotaan dan sosial ekonomi.

Menurut SK Walikota No 413.21/38.3/1/2016 tentang penetapan lokasi kawasan lingkungan perumahan dan permukiman kumuh di Surakarta yag telah diverifikasi, terdapat 28 kawasan permukiman kumuh yang terdiri dari 28 kawasan permukiman kumuh. Berdasarkan Dokumen Penyusunan Rencana Kawasan Permukiman Kumuh Perkotaan di Kota Surakarta tahun 2016, permukiman kumuh yang ada di Surakarta terdapat tiga tipologi, yaitu kawasan permukiman kumuh padat perkotaan, kawasan permukiman kumuh bantaran sungai dan kawasan permukiman kumuh sepanjang rel kereta api. Dalam dokumen RKPKP Surakarta disebutkan bahwa masalah utama penyebab kumuh adalah ketidakberdayaan masyarakat berpenghasilan rendah dalam pemenuhan rumah dan lingkungan yang sehat.

Dalam mengatasi kawasan permukiman kumuh, Pemerintah Kota Surakarta telah melakukan berbagai strategi, antara lain yaitu meningkatkan pemberdayaan masyarakat dalam pemenuhan rumah sehat dan lingkungan yang layak huni, penanganan banjir dan genangan, meningkatkan jumlah rumah layak huni, meningkatkan akses terhadap infrastruktur serta upaya penyediaan rumah layak huni yang legal (Dokumen RKPKP Kota Surakarta, 2016). Upaya yang dilakukan Pemerintah Kota Surakarta belum menunjukkan perubahan yang besar karena masih terdapat kawasan permukiman kumuh yang luas dan tersebar hampir di tiap kecamatan. Hal ini dikarenakan faktor utama atau faktor yang paling berkontribusi dalam mempengaruhi keberadaan kawasan permukiman kumuh di Surakarta belum diketahui. Oleh karena itu, penelitian ini perlu dilakukan agar mendapatkan output berupa faktor utama atau faktor dominan yang mempengaruhi keberadaan kawasan permukiman kumuh di Surakarta.

\section{KAJIAN TEORI}

Definisi kawasan permukiman kumuh adalah kawasan yang terabaikan dari pembangunan kota dengan kondisi lingkungan permukiman yang mengalami penurunan kualitas fisik, sosial ekonomi dan sosial budaya dan dihuni oleh orang-orang miskin, penduduk yang padat, serta dengan sarana prasarana yang minim. Ciri-ciri kawasan permukiman kumuh menurut Parsudi Suparlan (1984) yaitu dihuni oleh penduduk miskin yang bekerja pada sektor informal, serta dengan tingkat kepadatan penduduk yang tinggi dan tidak ditunjang dengan fasilitas yang memadai. Terdapat beberapa tipologi kawasan permukiman kumuh, namun tipologi kawasan permukiman kumuh yang ada di Surakarta menurut Dokumen RKPKP Kota Surakarta Tahun 2016 dibedakan menjadi 3 (tiga) tipologi. Ketiga tipologi kawasan permukiman kumuh tersebut yaitu permukiman kumuh padat perkotaan, permukiman kumuh bantaran sungai dan permukiman kumuh sepanjang rel kereta api.

Dalam menentukan faktor yang mempengaruhi keberadaan kawasan permukiman kumuh, digunakan sintesa teori yang diambil dari beberapa ahli/pakar yang menjelaskan teori terkait dengan permukiman kumuh. Teori tentang permukiman kumuh yang akan disintesa adalah teori mengenai faktor yang mempengaruhi keberadaan kawasan permukiman kumuh. Hasil sintesa teori tersebut akan digunakan sebagai variabel dalam penelitian yang dilakukan. Berikut ini merupakan variabel yang diambil dalam penelitian :

Tabel 1 Faktor yang Mempengaruhi Keberadaan Kawasan Permukiman Kumuh

\begin{tabular}{|c|c|l|}
\hline Variabel & Sub Variabel & \multicolumn{1}{|c|}{ Sumber } \\
\hline Faktor Urbanisasi & - & $\begin{array}{l}\text { Rindarjono (2013), Kementerian PUPR (2014), } \\
\text { Clinord (1978) }\end{array}$ \\
\hline $\begin{array}{c}\text { Faktor Sarana } \\
\text { Prasarana }\end{array}$ & Persampahan & \multicolumn{1}{|c|}{ Rindarjono (2013) } \\
\cline { 2 - 3 } & Air bersih & \\
\cline { 2 - 3 } & Sanitasi & \\
\hline Faktor Ekonomi & - & $\begin{array}{l}\text { Rindarjono (2013), Surtiani (2006), Kementerian } \\
\text { PUPR (2014) }\end{array}$ \\
\hline $\begin{array}{c}\text { Faktor Lahan } \\
\text { Perkotaan }\end{array}$ & - & Rindarjono (2013) \\
\hline Faktor Tata Ruang & - & $\begin{array}{l}\text { Rindarjono (2013), Surtiani (2006), Quick count } \\
\text { survey Kementerian PUPR (2014) }\end{array}$ \\
\hline
\end{tabular}




\begin{tabular}{|l|c|l|}
\hline Variabel & Sub Variabel & \multicolumn{1}{|c|}{ Sumber } \\
\hline $\begin{array}{l}\text { Faktor Daya Tarik } \\
\text { Perkotaan }\end{array}$ & - & Kementerian PUPR (2014) \\
\hline $\begin{array}{l}\text { Faktor Sosial } \\
\text { Budaya }\end{array}$ & - & Kementerian PUPR (2014) \\
\hline $\begin{array}{l}\text { Faktor Status } \\
\text { Kepemilikan } \\
\text { Bangunan }\end{array}$ & - & Surtiani (2006) \\
\hline $\begin{array}{l}\text { Faktor Lama } \\
\text { Tinggal Penghuni }\end{array}$ & - & Surtiani (2006) \\
\hline
\end{tabular}

Sumber : Clinord (1978), Rindarjono (2013), Surtiani (2006), Kementerian PUPR (2014)

\section{METODE PENELITIAN}

\subsection{RUANG LINGKUP PENELITIAN}

Terdapat tiga tipologi kawasan permukiman kumuh yang tersebar di Kota Surakarta, yaitu terdiri dari kawasan permukiman kumuh bantaran sungai (lihat gambar 1.), kawasan permukiman kumuh padat perkotaan (lihat gambar 2. )dan juga kawasan permukiman kumuh sepanjang rel kereta api (lihat gambar 3.). Pembagian tipologi kawasan kumuh tersebut berdasarkan lokasi kawasan permukiman kumuh yang tersebar di Surakarta.

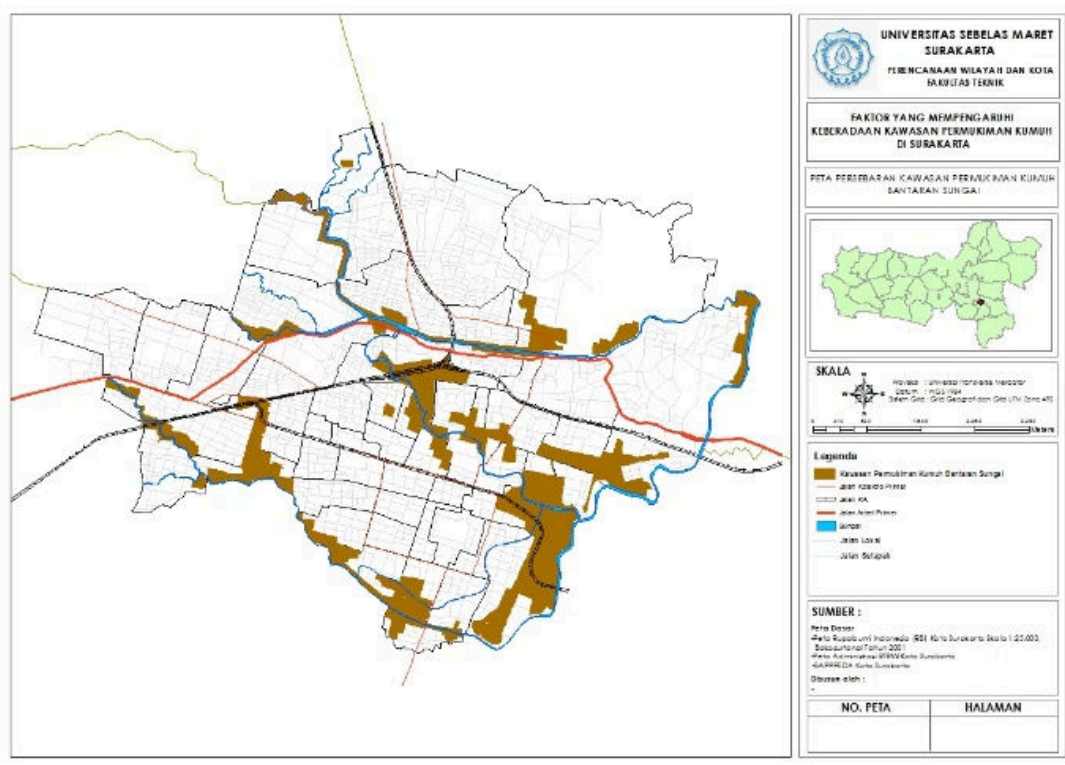

Sumber : Dokumen RKPKP Surakarta, 2016 berdasarkan SK Walikota No. 413.21/38.3/1/2016

Gambar 1. Peta Persebaran Kawasan Permukiman Kumuh Bantaran Sungai 


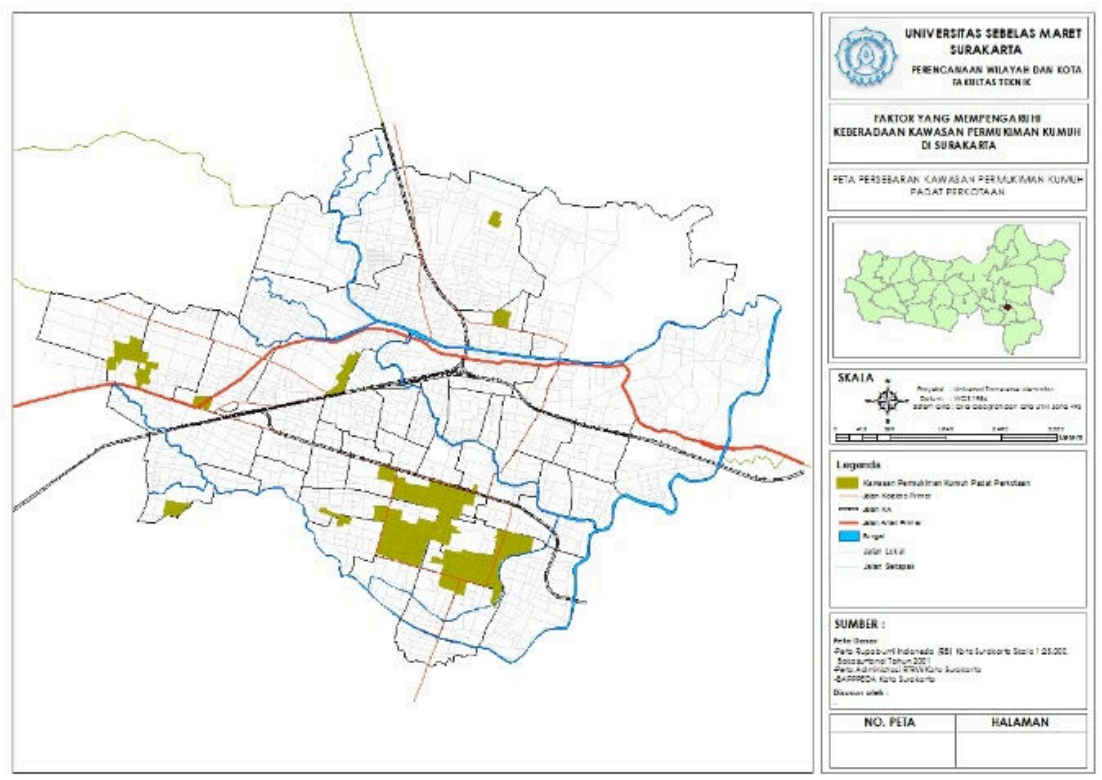

Sumber : Dokumen RKPKP Surakarta, 2016 berdasarkan SK Walikota No. 413.21/38.3/1/2016

Gambar 2. Peta Persebaran Kawasan Permukiman Padat Perkotaan

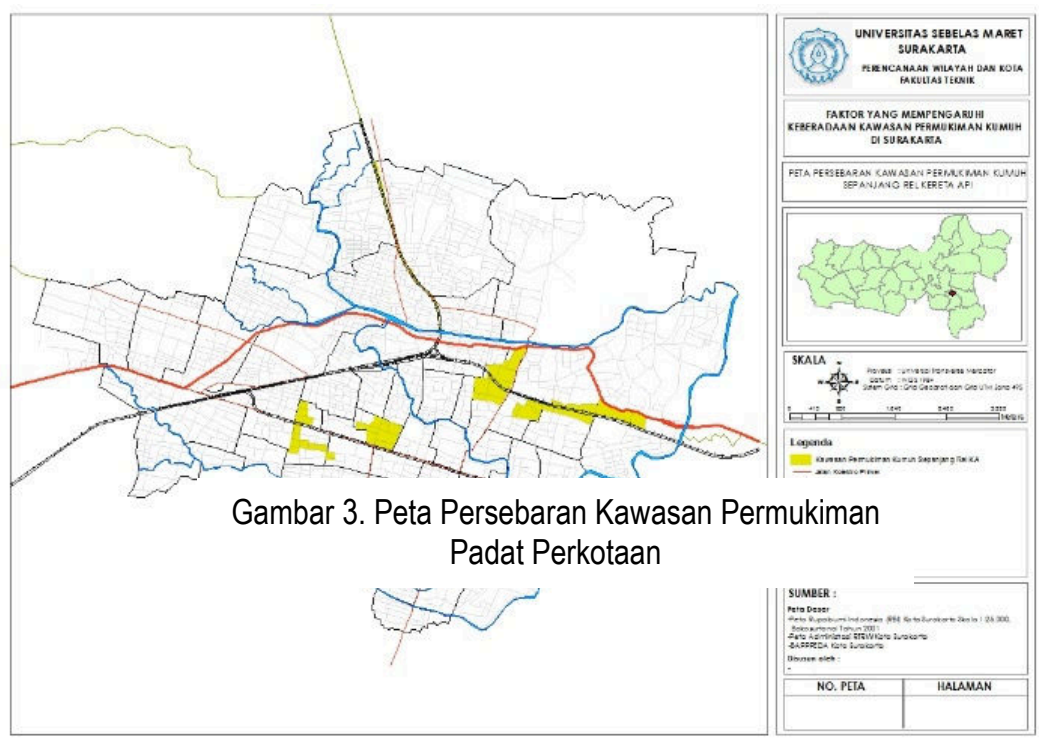

Sumber : Dokumen RKPKP Surakarta, 2016 berdasarkan SK Walikota No. 413.21/38.3/1/2016

Gambar 3. Peta Persebaran Kawasan Permukiman Padat Perkotaan

\subsection{PENDEKATAN DAN JENIS PENELITIAN}

Pendekatan penelitian ini dilakukan secara deduktif, sehingga peneliti berangkat dari teori untuk terjun ke lapangan dalam melakukan pencarian data yang kemudian dapat digunakan dalam meneliti faktor apa saja yang mempengaruhi keberadaan kawasan permukiman kumuh di Surakarta. Penelitian yang dilakukan merupakan jenis penilitian Kuantitatif. Penelitian iyang dilakukan menggunakan teknik AHP (Analithic Hierarchi Process) yang merupakan teknik analisis kuantitatif. Teknik ini mengubah pendapat-pendapat ahli/stakeholder terkait faktor yang mempengaruhi keberadaan kawasan permukiman kumuh di Surakarta menjadi nilai-nilai kuantitatif. AHP dalam penelitian ini digunakan 
untuk mengetahui faktor-faktor yang mempengaruhi dan faktor utama dalam mempengaruhi keberadaan kawasan permukiman kumuh di Surakarta.

\subsection{TEKNIK PENGUMPULAN DATA}

Teknik pengumpulan data yang dilakukan dalam penelitian ini adalah teknik wawancara, kuesioner dan strudi literature.Teknik wawancara / kuesioner dilakukan dengan cara menanyakan kebutuhan data penelitian secara langsung kepada narasumber yang dipilih. Sedangkan teknik studi literature menggunakan data sekunder yang didapatkan dari instansi pemerintahan, atau hasil penelitian yang sebelumnya. Pengumpulan data dengan dari studi literatur dan wawancara digunakan untuk memperkuat pembahasan faktor-faktor yang ada dalam penelitian sedangkan teknik kuesioner digunakan sebagai input data/dasar dalam melakukan analisis Analytic Hierarchy Process (AHP).

\subsection{TEKNIK ANALISIS DATA}

Penelitian mengenai faktor yang mempengaruhi keberadaan kawasan permukiman kumuh di Surakarta akan dilakukan dengan menggunakan analisis AHP. Hasil dari analisis AHP digunakan untuk menentukan faktor prioritas apa saja yang paling mempengaruhi keberadaan kawasan permukiman kumuh di Surakarta. Faktor yang mempengaruhi keberadaan kawasan permukiman kumuh ditiap tipologinya memiliki faktor yang sama, namun akan menghasilkan output prioritas yang berbeda tiap tipologinya berdasarkan hasil kuesioner yang diisi oleh stakeholder/ ahli. Stakeholdertersebut antara lain Dinas Perumahan, Kawasan Permukiman dan Pertanahan, DPUPR Bidang Pengendalian Ruang, Perencanaan Tata Ruang, Pemanfaatan Ruang dan Infrastruktur Permukiman, Badan Perencanaan dan Pembangunan (Badan Penataan Ruang dan Prasarana Kota), Akademisi dan LSM terkait.

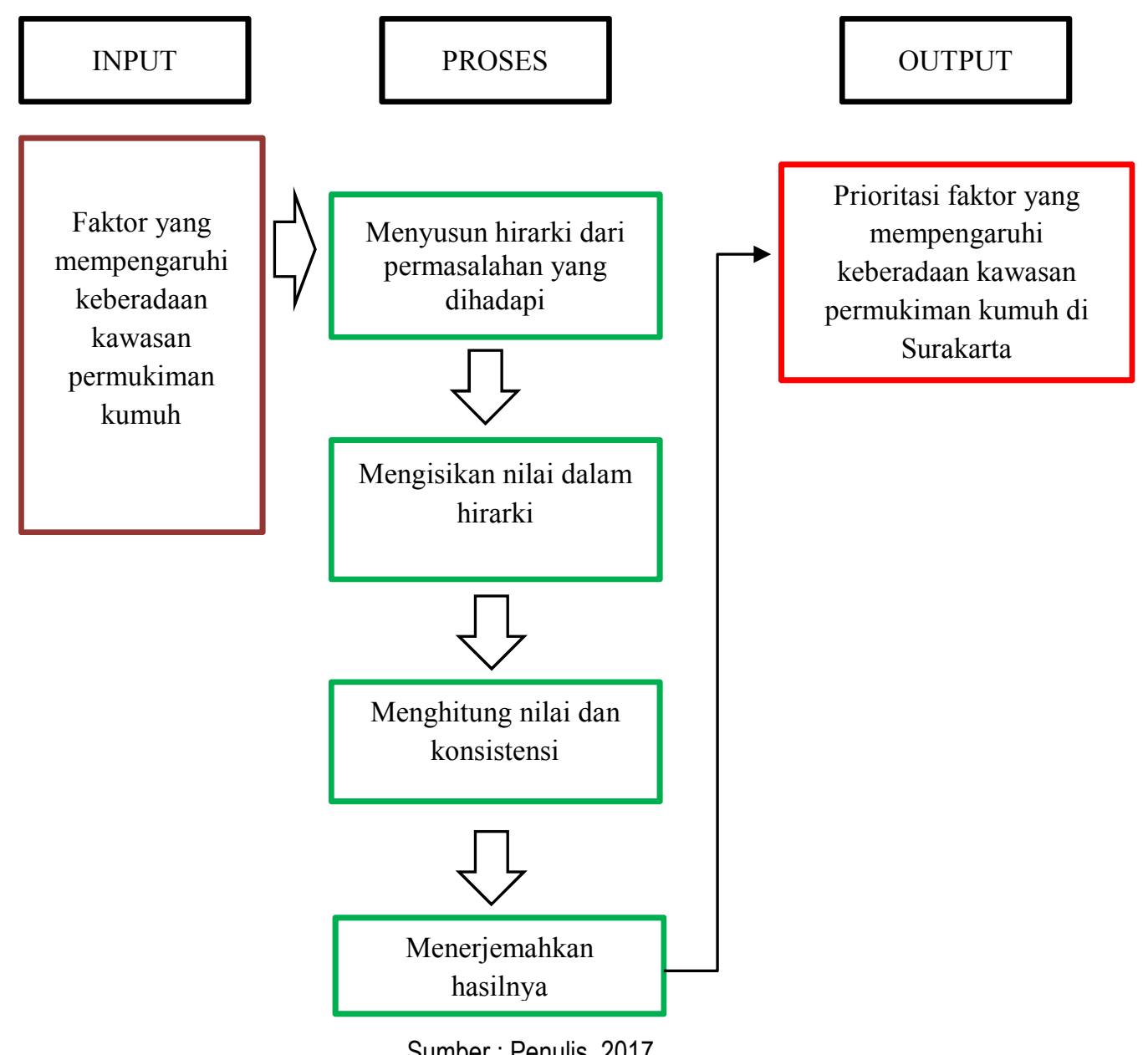

Gambar 4. Kerangka Analisis 


\title{
4. HASIL DAN PEMBAHASAN
}

Berdasarkan hasil analisis yang telah dilakukan, terdapat perbedaan antara faktor yang mempengaruhi keberadaan kawasan permukiman kumuh berdasarkan tipologi kawasan permukiman kumuh di Surakarta. Berikut merupakan penjelasan hasil prioritas faktor yang mempengaruhi keberadaan kawasan permukiman kumuh di Surakarta berdasarkan hasil AHP :

\subsection{KAWASAN PERMUKIMAN KUMUH BANTARAN SUNGAI}

Berdasarkan hasil prioritas faktor yang mempengaruhi keberadaan kawasan permukiman kumuh bantaran sungai diketahui bahwa tiga faktor prioritas yang paling mempengaruhi keberadaan kawasan permukiman kumuh bantaran sungai (lihat gambar 5). Ketiga faktor tersebut adalah faktor lahan perkotaan, faktor tata ruang dan faktor status kepemilikan bangunan. Faktor prioritas pertama yaitu faktor lahan perkotaan. Sesuai dengan pendapat Rindarjono (2013), bahwa keberadaan kawasan permukiman kumuh dipengaruhi oleh faktor lahan perkotaan, yaitu berupa peningkatan kebutuhan lahan untuk bertempat tinggal. Dengan keterbatasan lahan untuk permukiman di Surakarta, masyarakat mendirikan hunian dilahan yang tidak sesuai dengan peruntukannya dan menyebabkan keberadaan kawasan permukiman kumuh, seperti halnya pada kawasan permukiman kumuh bantaran sungai. Untuk faktor prioritas kedua yang paling penting dalam mempengaruhi keberadaan kawasan permukiman kumuh bantaran sungai yaitu faktor tata ruang. Seperti yang dikemukakan oleh para pakar/ ahli seperti Surtiani (2006), Rindarjono (2013) dan Kementerian PUPR (2014), bahwa faktor tata ruang dapat mempengaruhi keberadaan kawasan permukiman kumuh di Surakarta dikarenakan kurangnya pemahaman terhadap tata ruang. Pemahaman mengenai kesesuaian terhadap tata ruang dirasa penting bagi penduduk karena jika penduduk kurang memahami tentang kesesuaian pemanfaatan ruang, semakin mendorong penduduk mendirikan hunian di lahan yang tidak sesuai dengan peruntukan permukiman. Seperti halnya penduduk yang mendirikan hunian di sepanjang bantaran sungai yang lama kelamaan keberadaannya dapat menurunkan kualitas lingkungan dan menyebabkan adanya kawasan permukiman kumuh. Faktor prioritas ketiga yang paling penting dalam mempengaruhi keberadaan kawasan permukiman kumuh bantaran sungai yaitu faktor status kepemilikan bangunan. Menurut Surtiani (2006), bahwa status kepemilikan bangunan mempengaruhi cara pandang penduduk dalam menjaga kualitas hunian yang mereka tempati. Status kepemilikan bangunan di kawasan permukiman kumuh bantaran sungai merupakan kawasan kumuh dengan jumlah bangunan tidak memiliki status hak milik (SHM) paling banyak dibandingkan dengan kawasan permukiman kumuh lainnya. Hal ini dikarenakan penduduk yang menghuni bangunan di sepanjang sempadan sungai merasa tidak memiliki status hak milik atas bangunan yang mereka tempati. Oleh karena itu, penduduk lebih enggan untuk memperbaiki hunian tersebut yang menyebabkan semakin lama kualitas hunian menurun karena bangunan yang ada bersifat non permanen.

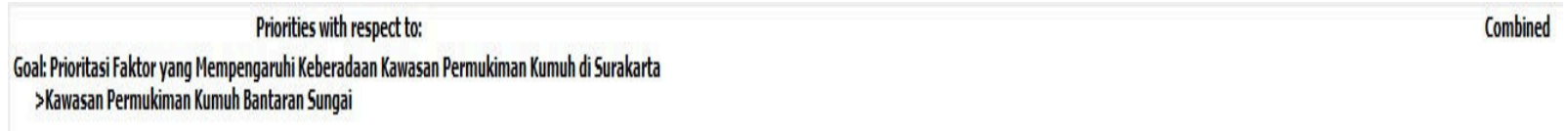

Faktor Lahan Perkotaan
Faktor Tata Ruang
Faktor Status Kepemilikan Bangunan
Faktor Ekonomi
Fakktor Sarana Prasararana
Fakttor Daya Tarik Perkotaan
Faktor Urbanisasi
Faktor Lama Tinggal Penghguni
Faktor Sosial Budaya
Inconsistency = 0,07
with 0 missing judgments.

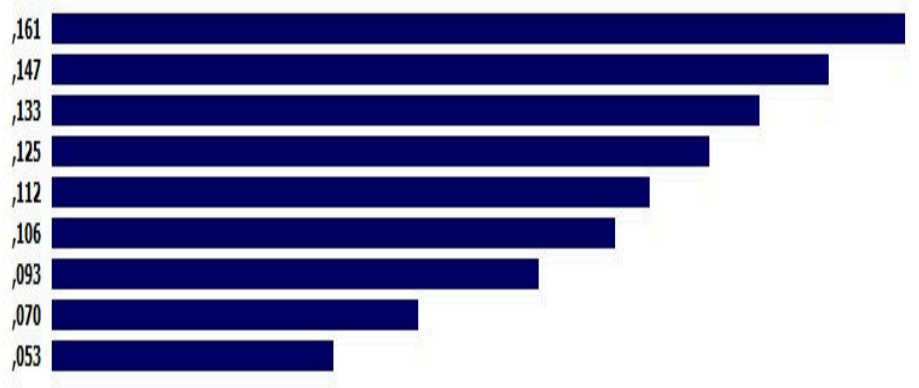

Sumber : Analisis, 2017

\author{
Gambar 5. Prioritas Faktor yang Mempengaruhi Keberadaan Kawasan Permukiman Kumuh Bantaran \\ Sungai
}


Untuk tiga faktor yang bukan merupakan faktor prioritas dalam mempengaruhi keberadaan kawasan permukiman kumuh bantaran sungai yaitu faktor lama tinggal penghuni, faktor sarana prasarana dan faktor sosial budaya (lihat gambar 4.). Faktor lama tinggal penghuni menurut Surtiani (2006) yaitu semakin lama penduduk yang yang mendiami hunian dengan kondisi non permanen akan menurunkan kualitas hunian dan menjadikan lingkungan kawasan tersebut menjadi kumuh. Kondisi ini sebanding dengan fakta dilapangan bahwa penduduk yang melakukan urbanisasi dan menetap di Surakarta memaksa mereka untuk membangun hunian dilahan yang tidak sesuai dengan peruntukan permukiman, seperti pada bantaran sungai, dengan kondisi bangunan non permanen yang semakin lama akan mengalami penurunan kualitas hunian dan menyebabkan kekumuhan lingkungan. Faktor kedua yang bukan merupakan faktor prioritas yang dapat mempengaruhi keberadaan kawasan permukiman kumuh di bantaran sungai adalah faktor sarana prasarana. Menurut Rindarjono (2013), permukiman yang tidak ditunjang dengan sarana prasarana permukiman akan menyebabkan lingkungan permukiman tersebut menjadi kotor dan kumuh. Untuk faktor ketiga yang bukan merupakan faktor prioritas yang dapat mempengaruhi keberadaan kawasan permukiman kumuh di bantaran sungai yaitu faktor sosial budaya. Faktor sosial budaya merupakan faktor yang disebutkan oleh Kementerian PUPR (2014). Seperti halnya di Surakarta yang dihuni oleh penduduk dari struktur dan norma yang berbeda-beda. Hal ini sesuai dengan hasil analisis yang dilakukan, bahwa kawasan permukiman kumuh bantaran sungai dihuni oleh penduduk dengan mata pencaharian, tamatan pendidikan dan agama yang beragam. Hal tersebut berdampak pada kualitas hubungan yang ada di kawasan permukiman kumuh bantaran sungai, yangmana kualitas hubungan akan mempengaruhi dalam meningkatkan kesejahteraan penduduk di kawasan kumuh tersebut. Namun, berdasarkan hasil analisis AHP, ketiga faktor tersebut, yaitu faktor lama tinggal penghuni, faktor sarana prasarana dan faktor sosial budaya bukan merupakan faktor prioritas yang dapat mempengaruhi keberadaan kawasan permukiman kumuh di bantaran sungai.

\subsection{KAWASAN PERMUKIMAN KUMUH PADAT PERKOTAAN}

Berdasarkan analisis AHP, terdapat tiga faktor prioritas teratas yang paling mempengaruhi keberadaan kawasan permukiman padat perkotaan, yaitu faktor lahan perkotaan, faktor tata ruang dan faktor ekonomi (lihat gambar 5.). Faktor prioritas pertama yaitu faktor lahan perkotaan. Hal ini didukung dengan hasil analisis bahwa di Surakarta terjadi peningkatan lahan untuk permukiman sebesar 71,36 hektar selama kurun waktu lima tahun terakhir. Dalam hal ini permukiman yang terus bertambah padat di perkotaan, namun tidak didukung dengan sarana prasarana penunjang permukiman yang jelas menyebabkan adanya permukiman kumuh padat perkotaan. Faktor prioritas kedua yaitu faktor tata ruang. Berdasarkan pendapat Surtiani (2006), Rindarjono (2013) dan Kementerian PUPR (2014), faktor tata ruang yang dapat mempengaruhi keberadaan kawasan permukiman kumuh dikarenakan kurangnya pemahaman terhadap tata ruang. Masyarakat pendatang yang mendirikan hunian di kota Surakarta tanpa memperhatikan dan memahami tata ruang yang menyangkut kesesuaian lahan untuk permukiman, semakin lama mereka mendirikan hunian di lahan yang tidak sesuai dengan peruntukannya menyebabkan penurunan kualitas lingkungan yang menyebabkan kekumuhan. Faktor ketiga yang merupakan faktor prioritas dalam mempengaruhi keberadaan kawasan permukiman kumuh adalah faktor ekonomi. Adanya masyarakat berpenghasilan rendah di kawasan permukiman kumuh padat perkotaan sesuai dengan teori yang disebutkan oleh Rindarjono (2013), Surtiani (2006) dan Kementerian PUPR (2014). Dalam teori tersebut dikatakan bahwa MBR mempengaruhi keberadaan kawasan permukiman kumuh karena penduduk tidak mampu membeli dan mendirikan bangunan yang layak, sehingga mereka mendirikan hunian di lahan yang tidak sesuai dengan peruntukannya dan semakin lama dapat menurunkan kualitas hunian dan lingkungan yang mengakibatkan kawasan tersebut menjadi kumuh.

Tiga faktor prioritas yang bukan merupakan faktor dalam mempengaruhi keberadaan kawasan permukiman kumuh padat perkotaan adalah faktor sarana prasarana, faktor lama tinggal penghuni dan faktor sosial budaya (lihat gambar 6.). Faktor sarana prasarana yang dimaksud menurut Rindarjono (2013), jika permukiman tidak terlayani sarana prasarana berupa air bersih, sanitasi dan persampahan dengan baik, akan menyebabkan lingkungan permukiman tersebut menjadi kotor dan kumuh. Faktor kedua yang bukan merupakan faktor dalam mempengaruhi keberadaan kawasan permukiman kumuh padat perkotaan yaitu faktor lama tinggal penghuni. Menurut Surtiani (2006), semakin lama penduduk yang yang mendiami hunian dengan kondisi non permanen akan menurunkan kualitas hunian dan menjadikan lingkungan kawasan tersebut menjadi kumuh. 


Faktor Lahan Perkotaan
Faktor Tata Ruang
Fakktor Ekonomi
Faktor Daya Tarik Perkotaan
Fakktor Status Kepenilikan Bangunan
Fakktor Sarana Prasararana
Faktor Urbanisasi
Faktor Lama Tinggal Penghuni
Fakktor Sosial Budaya
Inconsistency = 0,09
with 0 missing judgments.

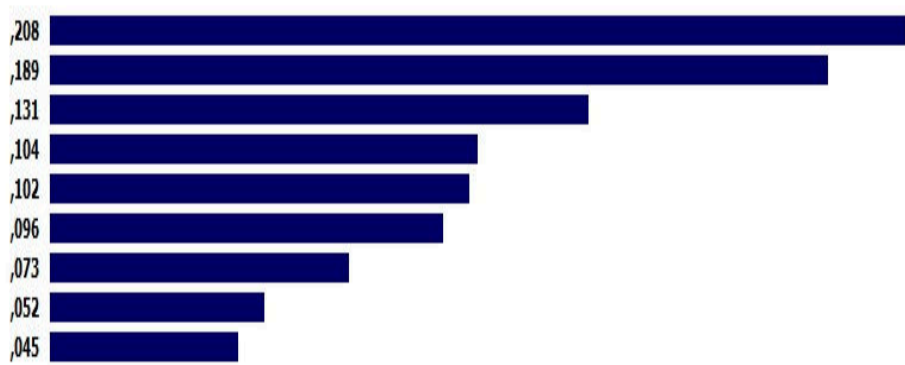

Sumber : Analisis, 2017

Gambar 6. Grafik Prioritas Faktor yang Mempengaruhi Keberadaan Kawasan Permukiman Kumuh Padat Perkotaan di Surakarta

Penduduk yang mendirikan hunian di pusat kota tanpa memperhatikan kesesuaian terhadap peruntukan bangunan dengan penghasilan rendah, sehingga hanya mampu membangun hunian dengan kondisi bangunan non permanen. Apabila hal ini berlangsung terus-menerus, akan menyebabkan hunian tidak layak dan padat di perkotaan dapat membuat lingkungan permukiman mengalami pernurunan kualitas hunian, sehingga menyebabkan kekumuhan di perkotaan Surakarta. Meskipun teori yang dikemukakan oleh Surtiani (2006) sesuai dengan fakta di lapangan, namun dari hasil analisis AHP, faktor lama tinggal penghuni tidak menjadi faktor prioritas dalam mempengaruhi keberadaan kawasan permukiman kumuh padat perkotaan. Faktor terakhir yaitu faktor sosial budaya yang merupakan faktor yang disebutkan oleh Kementerian PUPR (2014). Berdasarkan analisis yang dilakukan, kawasan permukiman kumuh di Surakarta dihuni oleh penduduk dari struktur dan norma yang beragam. Hal ini sesuai hasil analisis yang dilakukan, bahwa kawasan permukiman kumuh padat perkotaan dihuni oleh penduduk dengan mata pencaharian, tamatan pendidikan dan agama yang beragam. Keberagaman tersebut, berdampak pada kualitas hubungan yang ada di kawasan permukiman kumuh padat perkotaan. Semakin buruk kualitas hubungan yang ada, semakin sulit untuk meningkatkan kesejahteraan bersama karena pada kawasan permukiman kumuh padat perkotaan dihuni oleh masyarakat dengan penghasilan rendah yang tidak mampu mendirikan hunian layak. Namun, meskipun data yang diperoleh sesuai dengan teori yang ada, berdasarkan hasil prioritas dengan analisis AHP, faktor sosial budaya merupakan faktor urutan terakhir atau faktor ini bukan merupakan faktor prioritas dalam mempengaruhi keberadaan kawasan permukiman kumuh padat perkotaan.

\subsection{KAWASAN PERMUKIMAN KUMUH SEPANJANG REL KERETA API}

Dari hasil analisis prioritas faktor dengan metode AHP, didapatkan tiga faktor utama yang paling mempengaruhi keberadaan kawasan permukiman kumuh sepanjang rel kereta api (lihat gambar 7.). Faktor pertama yaitu faktor status kepemilikan bangunan. Menurut teori yang dikemukakan oleh Surtiani (2006) status kepemilikan bangunan mempengaruhi cara pandang penduduk dalam menjaga kualitas hunian yang mereka tempati. Cara pandang penduduk yang bertempat tinggal di kawasan permukiman kumuh sepanjang rel kereta api menganggap bahwa hunian yang mereka tempati adalah hunian sementara yang bersifat non permanen, sehingga penduduk enggan memperbaiki hunian tersebut menyebabkan semakin lama kualitas hunian menurun dan mengakibatkan lingkungan permukiman menjadi kumuh. Kedua yaitu faktor ekonomi. Menurut Rindarjono (2013), Surtiani (2006) dan Kementerian PUPR (2014), rendahnya tingkat penghasilan dilihat berdasarkan kemampuan penduduk dalam melakukan perbaikan huniannya. Jumlah masyarakat berpenghasilan rendah (MBR) di kawasan permukiman kumuh sepanjang rel kereta api paling banyak dibandingkan dengan kawasan permukiman kumuh lainnya. Dengan demikian menyebabkan penduduk yang memiliki penghasilan rendah tersebut tanpa pikir panjang dan karena kondisi yang tidak berkecukupan, akhirnya memakasa mereka mendirikan hunian di sepanjang rel kereta api yang keberadaannya tidak sesuai dengan rencana pola ruang permukiman. Hal tersebut semakin lama dapat berdampak pada kekumuhan lingkungan permukiman. Hunian yang dibangun di lahan tidak sesuai dengan peruntukan tersebut memiliki kondisi bangunan yang non permanen 
dan tidak memiliki status kepemilikan bangunan, sehingga penduduk yang bertempat tinggal di kawasan sepanjang rel kereta api enggan untuk menjaga kualitas hunian dan lingkungannya, sebab mereka merasa tidak memiliki hunian tersebut. Akibatnya, kawasan tempat tinggal mereka menjadi kotor dan kumuh karena menjaga kebersihan dan kepedulian terhadap lingkungan tempat tinggal mereka yang masih rendah. Faktor prioritas ketiga adalah faktor tata ruang. Menurut Surtiani (2006), Rindarjono (2013) dan Kementerian PUPR (2014), menyatakan bahwa faktor tata ruang yang dapat mempengaruhi keberadaan kawasan permukiman kumuh di Surakarta dikarenakan kurangnya pemahaman terhadap tata ruang. Hal ini dibuktikan dengan hasil analisis yang membuktikan bahwa masih terdapat hunian yang tidak sesuai dengan rencana pola ruang permukiman di sepanjang rel kereta api. ketiga faktor tersebut merupakan faktor yang paling mempengaruhi keberadaan kawasan permukiman kumuh sepanjang rel kereta api.

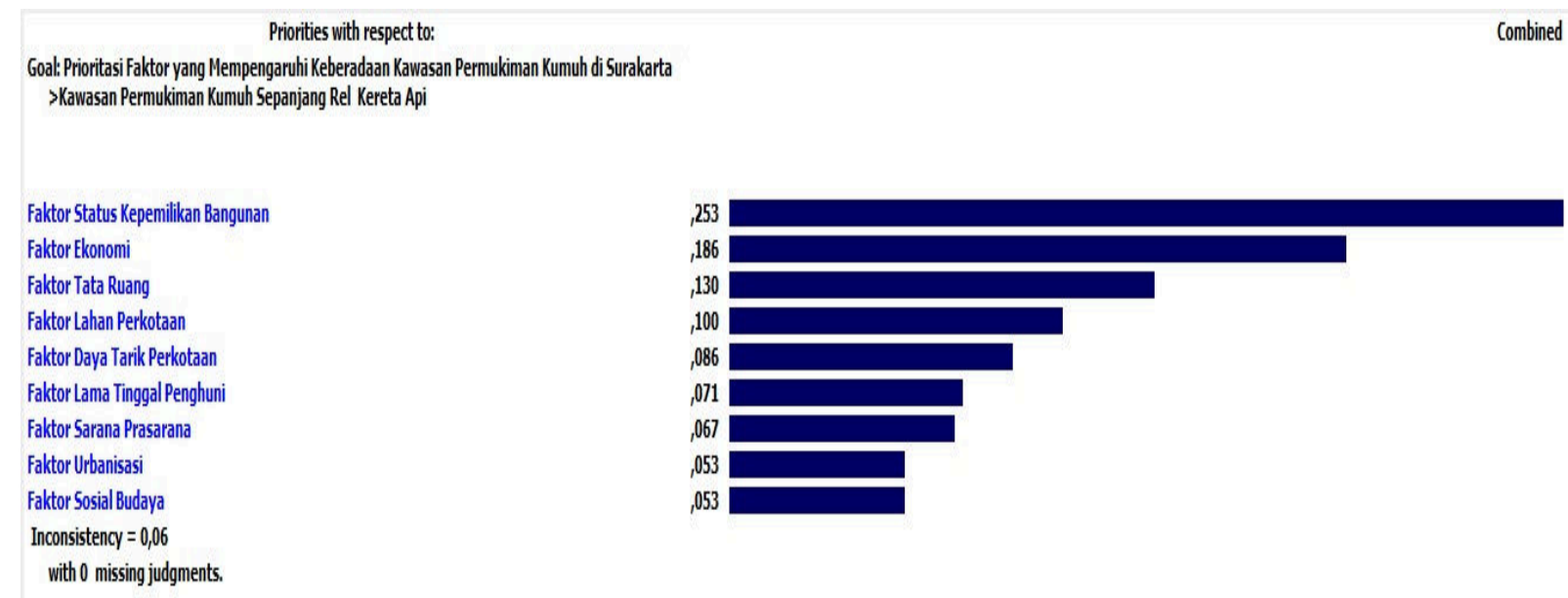

Sumber : Analisis, 2017

Gambar 7. Grafik Prioritas Faktor yang Mempengaruhi Keberadaan Kawasan Permukiman Kumuh Sepanjang Rel Kereta Api di

Adapun tiga faktor yang bukan menjadi prioritas dalam mempengaruhi keberadaan kawasan permukiman kumuh sepanjang rel kereta api yaitu faktor urbanisasi, faktor sarana prasarana dan faktor sosial budaya (lihat gambar 6.). Menurut Rindarjono (2013), Surtiani (2006) dan Kementerian PUPR (2014), menyebutkan bahwa faktor urbanisasi dilihat dari pertambahan jumlah penduduk yang terus mengalami peningkatan. Dari hasil analisis yang dilakukan, diketahui bahwa ternyata jumlah penduduk di kawasan permukiman kumuh yang dilihat menurut jumlah penduduk berdasarkan kelurahan di Surakarta selama kurun waktu 5 tahun terakhir (2013-2017), pada tahun 2015 jumlah penduduk mengalami penurunan. Melihat kondisi tersebut dapat disimpulkan bahwa faktor urbanisasi yang dikemukakan oleh ahli kurang sesuai dengan fakta yang ada di lapangan. Selain itu, berdasarkan analsiis AHP yang dilakukan, faktor urbanisasi bukan merupakan faktor prioritas yang mempengaruhi keberadaan kawasan permukiman kumuh sepanjang rel kereta api. Berikutnya yaitu faktor sarana prasarana. Menurut Rindarjono (2013), faktor sarana prasarana berupa air bersih, sanitasi dan persampahan merupakan faktor penting dalam mempengaruhi keberadaan kawasan permukiman kumuh karena permukiman kumuh terjadi akibat tidak terlayaninya infrastruktur dasar permukiman.

Dari hasil analisis yang telah dilakukan, masih terdapat hunian yang belum terlayani sarana prasarana di kawasan permukiman kumuh sepanjang rel kereta api. Akibatnya, hunian yang ada di kawasan sepanjang rel kereta api tersebut dapat dikatakan belum memenuhi standar permukiman layak, yang tentunya akan mempengaruhi keberadaan permukiman kumuh sepanjang rel kereta api. Meskipun sesuai dengan teori, namun berdasarkan analisis AHP yang dilakukan, faktor ini bukan merupakan faktor prioritas yang dapat mempengaruhi keberadaan kawasan permukiman kumuh sepanjang rel kereta api. Faktor terakhir yaitu faktor sosial budaya. Berdasarkan teori yang dikemukakan oleh Kementerian PUPR (2014), faktor sosial budaya berupa keberagaman struktur dan norma penduduk dapat mempengaruhi kualitas hubungan antar penduduk yang ada di kawasan tersebut. Dari hasil analisis yang dilakukan, diketahui bahwa kawasan permukiman kumuh di Surakarta, termasuk kawasan permukiman kumuh sepanjang rel kereta api dihuni oleh penduduk dari struktur dan norma yang berbeda-beda. Hal ini sesuai dengan data yang diperoleh, 
bahwa kawasan permukiman kumuh sepanjang rel kereta api dihuni oleh penduduk dengan mata pencaharian, tamatan pendidikan dan agama yang beragam karena keberagaman tersebut, berdampak pada kualitas hubungan yang ada di kawasan permukiman kumuh sepanjang rel kereta api. Oleh karena itu, sesuai dengan teori yang disebutkan oleh Kementerian PUPR (2014) bahwa faktor sosial budaya dapat mempengaruhi keberadaan kawasan permukiman kumuh. Namun, faktor ini bukan merupakan faktor prioritas dalam mempengaruhi keberadaan kawasan permukiman kumuh sepanjang rel kereta api.

\section{KESIMPULAN}

Faktor yang mempengaruhi keberadaan kawasan permukiman kumuh di Surakarta dapat dilihat dari beberapa faktor. Faktor-faktor tersebut yaitu faktor urbanisasi, faktor sarana prasarana, faktor ekonomi, faktor lahan perkotaan, faktor tata ruang, faktor daya tarik perkotaan, faktor sosial budaya, faktor status kepemilikan bangunan dan faktor lama tinggal penghuni. Faktor prioritas untuk tipologi kawasan permukiman kumuh bantaran sungai, kawasan permukiman kumuh padat perkotaan dan kawasan permukiman kumuh sepanjang rel kereta api berbeda-beda.

Untuk kawasan permukiman kumuh bantaran sungai, tiga faktor prioritas yang paling mempengaruhi keberadaan kawasan permukiman kumuh bantaran sungai adalah faktor lahan perkotaan, faktor tata ruang dan faktor status kepemilikan bangunan. Tiga faktor prioritas yang mempengaruhi keberadaan kawasan permukiman kumuh padat perkotaan yaitu faktor lahan perkotaan, faktor tata ruang dan faktor ekonomi. Sedangkan tiga faktor prioritas yang paling mempengaruhi keberadaan kawasan permukiman kumuh sepanjang rel kereta api adalah faktor status kepemilikan bangunan, faktor ekonomi dan faktor tata ruang.

\section{DAFTAR PUSTAKA}

\section{Buku}

Clinord, Marshal, B. 1978. Slum and Community Development, Collier Macmillan Canada Ltd, Toronto-Ontario

Parsudi, S. 1984. "Kebudayaan Kemiskinan, dalam Kemiskinan di Perkotaan". Jakarta: Yayasan Obor Indonesia - Sinar Harapan

Rindarjono, Mohammad Gamal. 2013. Slum Kajian Permukiman Kumuh Dalam Perspektif Spasial. Yogyakarta : Media Perkasa.

\section{Jurnal}

Surtiani. 2006. "Faktor-faktor yang Mempengaruhi Terciptanya Kawasan Permukiman Kumuh di Kawasan Pusat Kota (Studi Kasus: Kawasan Pancuran, Salatiga". Semarang

\section{Dokumen Pemerintah}

Direktorat Pengembangan Permukiman. Direktorat Jenderal Pajak. Kementerian Pekerjaan Umum. 2014. "Paduan Kegiatan Quick Count Identifikasi Kawasan Permukiman Kumuh"

Dokumen RKPKP Kota Surakarta Tahun 2016

Panduan Identifikasi Kawasan Permukiman Kumuh

Paparan Akhir "Dokumen Rencana Kawasan Permukiman Kumuh Perkotaan (RKPKP) Surakarta". 2015

RPJMN Ditjen Cipta Karya 2015-2019

SK Walikota No 32/97-C/1/2014 Tentang Penetapan Lokasi Perumahan Dan Permukiman Kumuh Di Surakarta. 